\title{
Belphégor
}

\section{Special Issue on Élisabeth Vonarburg, Guest Editor Amy Ransom}

Femspec, vol.11, Issue 2, 2011, 194p. Issn 1523-4002.

\section{Sophie Beaulé}

\section{(2) OpenEdition}

\section{Journals}

Electronic version

URL: http://journals.openedition.org/belphegor/171

DOI: 10.4000/belphegor.171

ISSN: 1499-7185

\section{Publisher}

LPCM

\section{Electronic reference}

Sophie Beaulé, «Special Issue on Élisabeth Vonarburg, Guest Editor Amy Ransom », Belphégor [Online], 11-1 | 2013, Online since 29 April 2013, connection on 22 September 2020. URL : http:// journals.openedition.org/belphegor/171 ; DOI : https://doi.org/10.4000/belphegor.171

This text was automatically generated on 22 September 2020.

\section{@(@) $\Theta \Theta$}

Belphégor est mis à disposition selon les termes de la Licence Creative Commons Attribution - Pas d'Utilisation Commerciale - Pas de Modification 4.0 International. 


\section{Special Issue on Élisabeth} Vonarburg, Guest Editor Amy

\section{Ransom}

Femspec, vol.11, Issue 2, 2011, 194p. Issn 1523-4002.

Sophie Beaulé

\section{REFERENCES}

Special Issue on Élisabeth Vonarburg, Guest Editor Amy Ransom, Femspec, vol. 11, Issue 2, 2011, 194p. Issn 1523-4002 
1 At last, a special issue in English on Élisabeth Vonarburg, the "Grande Dame" of Quebec Science Fiction! Though scholars and critics have written dissertations and articles on Vonarburg's work, this long-awaited issue of Femspec is the first volume of academic papers in Philip K. Dick's language to have been published on this important francophone SF and Fantasy writer.

2 Vonarburg has to date received over thirty awards and official mentions. To name just a few, in 1982, for her very first novel, Vonarburg received "Le Grand Prix de la SF française." In 1992, she received the "Special Citation" of the Philip K. Dick Award, for In the Mother's Land. Two years later, she was nominated again for that

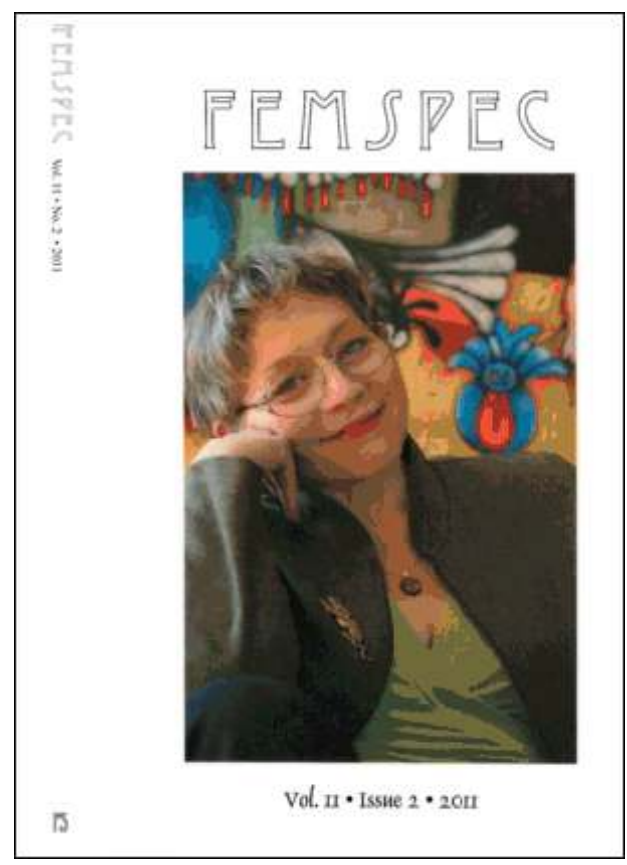
award, for Reluctant Voyagers. Vonarburg has also received the Prix du Conseil québécois de la Femme en littérature (1988), given only once, to celebrate the $20^{\text {th }}$ anniversary of the Council.

Élisabeth Vonarburg is not only a most talented writer; she has also worked hard to settle and nurture the contemporary Quebec SF and fantasy milieu.

4 The feminist journal Femspec was well-inspired to invite Amy Ransom, the foremost American scholar on Quebec SF and fantasy, to oversee the issue. Ransom made sure that the reader who is not familiar with Vonarburg's work will discover her fictional universe, and that the well-acquainted one will be able to deepen her appreciation of it. As a gesture to Vonarburg's "consistent effort to reach out to offer another voice to the dominant Anglo-American sf scene" (Introduction, p. 23), Ransom translated into English an interview and an Afterword originally conducted and written in French. Another article in the Dossier is both in English and French.

5 I will concentrate on the Dossier itself, leaving the rest of the issue to the reader's pleasure of discovery. Let me just mention the discussion later on of Amy Ransom's Science Fiction from Québec: A Postcolonial Study (2009), a study that includes an analysis of Vonarburg's work.

6 The issue opens with an insightful introduction by Amy Ransom and a brief biography. Ransom underlines the contribution to the genre of the work of Vonarburg that is mainly concerned with feminism, The Silent City (1982)/ In the Mother's Land (1992). Not only do these novels converge on Ursula Le Guin's work, for instance, but they antedate both Monique Wittig's and Hélène Cixous' works, as both Miléna Santoro's interview with the writer and Vonarburg's Afterword indicate. They also antedate Margaret Atwood's The Handmaid's Tale (1985) and Pamela Sargent's The Shore of Women (1986). In analysing the Baiblanca cycle, Ransom examines its links with Vonarburg's two early feminist novels, the Tyranaël pentalogy (1995-1996) and, especially, the Bridge cycle. Ransom rightly finds themes in the Baiblanca cycle that are mirrored in the entire work, such as the frontier between art and reality, nature and artifice, the human and 
the non-human. The Tyranaël cycle presents a planet opera that compares favourably to Kim Stanley Robinson's Mars trilogy (1992-1996) for its powerful imagination and complexity. Finally, Ransom does not forget the other stories, loosely connected to the above-mentioned cycles, or the most recent cycle, Reine de Mémoire (Queen of Memory, 2005-2007).

7 A review of the scholarship published in English concludes the introduction, along with a bibliography of Vonarburg's works available in English. Ransom's respect for Vonarburg, whom she calls the Queen of Memory-for her life, her desire to provide women with memory, and her involvement in the Quebec SF milieu-is palpable.

Most fascinating is the interview conducted by Miléna Santoro and her students, "From Silence to Memory: An Interview with Élisabeth Vonarburg". In my opinion, this is among the best interviews I have read; though it repeats some comments published in other venues, the questions lead to new details and reflections from the writer. The interview concentrates first on the early part of Vonarburg's career, particularly on Chroniques du Pays des Mères (In Mother's Land). Vonarburg shares with humour her reflections on feminism and on her identity as an "eco-feminist". There is an "obligatory convergence" (p.33) between utopian or para-utopian Science Fiction and women, since SF allows elaboration of divergent worlds and societies: this is how Vonarburg came to feminism. Through feminism, the writer comes back to The Silent City and In the Mother's Land-their creation, characters, the question of power and linguistic genres, myths, religion.... Religion is also found in Reine de Mémoire, another award-winning fictional universe, and the subject of the second part of the interview. Vonarburg shares her thoughts about the genesis of the pentalogy, along with its fantasy, SF and uchronic aspects. She also speaks about the links between this set of novels and her family history.

9 Two articles echo comments made in the Introduction and the interview. In "Reluctant Travelers: Vonarburg's Postcolonial Posthuman Voyagers", Anna Bedford investigates the figure of the traveller found in Reluctant Voyagers and The Silent City. Unlike the traditional figure of the neutral traveller, Vonarburg's female protagonists are characterized by unstable identity and memory, and the perception that reality and truth are multiple. "Transformed in a posthuman, postcolonial, feminist context" (p. 69), the travellers cope with a challenging environment with which they must reach a mutual understanding, in the mode of the "Canadian trope of survival" (p. 73). They experiment with a metamorphosed body, one that blurs the distinction between male and female identities. The travellers trigger a new relation between the Self and the Other, a new sensibility - diverging from the humanistic conception of an universal human being, a conception that informs much traditional SF.

The richness of Vonarburg's fictional universes includes a refined use of language that goes beyond what one generally finds in SF works. The question of gender and subject analyzed by Bedford finds realization on lexical and syntactic levels, a point Sharon Taylor examines in her very well-crafted study “'Sexualects' in Vonarburg's In the Mother's Land". In order to investigate the linguistic gender estrangement found in In the Mother's Land, Taylor coins the term "sexualect", which names "the social and sexual character of language" (p. 86). Inspired by the specialist of utopia Guy Bouchard, Taylor constructed the term from Mikhail Bakhtin, Roland Barthes, Julia Kristeva, Hélène Cixous and Luce Irigaray. Vonarburg's characters in The Silent City reject the authoritarian patriarchy and its male-centered language that transforms the feminine 
subject into a non-presence. The new matriarchal regime that soon replaces the former one reverses the status of males, builds a new religion, and, thereby, presents a femalecentered sexualect through new lexical and syntactical constructions. Ultimately, the protagonist will question this new authority... "Defamiliarization," or estrangement through parody, and the deconstruction of grammar, Taylor says, allow Vonarburg to question history, social institutions, and language in order to reframe them, and mostly to free the individual from any sexual, linguistic, or cultural identity that would determine her place in a society.

11 It is this refusal to be categorized that motivates Vonarburg in her Afterword: "I am first and foremost a woman who writes fiction" (p. 115). Feminism is not an answer, but a question; the revelation that James Tiptree Jr. was a woman changed Vonarburg's life and brought her to reflect on the "nature" of the "feminine" and of the "masculine" of the human. Only fiction can really embody theory, and fiction escapes theories like "the real itself, this obscure object of desire" (p. 117). 